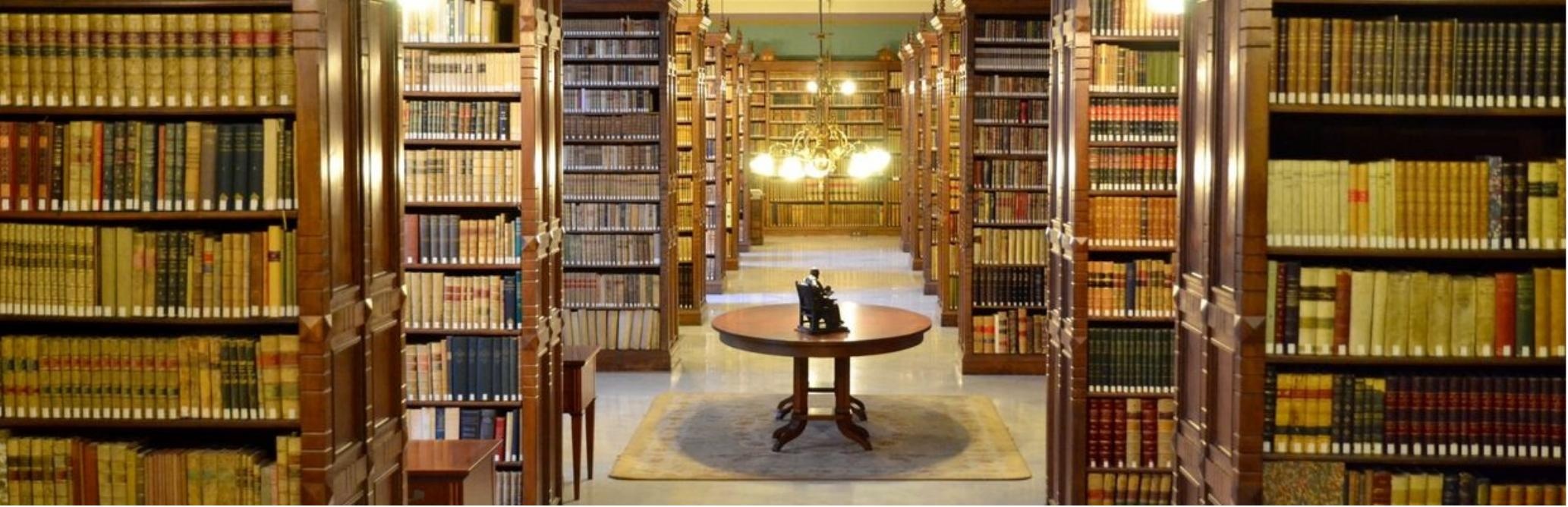

\title{
Editorial Volume 7, Issue 2
}

$\begin{aligned} \text { Authors: } & \text { María Fernanda Sandoval } \\ \text { Submitted: } & 29 . \text { April } 2020 \\ \text { Published: } & 30 . \text { April } 2020 \\ \text { Volume: } & 7 \\ \text { Issue: } & 2 \\ \text { Affiliation: } & \text { IASHA e.V., Freiburg, Germany } \\ \text { Languages: } & \text { English } \\ \text { Keywords: } & \text { Editorial, Josha Journal, } 2020 \text { March - April } \\ \text { Categories: } & \text { News and Views } \\ \text { DOI: } & 10.17160 / \text { josha.7.2.669 }\end{aligned}$

Abstract:

Dear JOSHA readers, once again we find ourselves saying goodbye and closing another wonderful issue! As you may have noticed, our bi-monthly editions are made up of more than ten articles throughout February and March. With this change we have achieved an incredible variety of topics within the same edition, covering literally all our areas and also giving space to current opinion articles, for example in relation to society and the effects of COVID -19. In addition to this change, we would like to remind you of our current Demetrios Award 2020. Don't forget that you can now submit your research and opt for the 500 Euro prize plus publication of the work in our Journal.

\section{JOSHA Jouma olseserea Humanities and Arts




\section{JOSHA - Journal of Science Humanities and Arts Editorial Volume 7 Issue 2}

Dear JOSHA readers, once again we find ourselves saying goodbye and closing another wonderful issue!

As you may have noticed, our bi-monthly editions are made up of more than twenty articles throughout February and March. With this change we have achieved an incredible variety of topics within the same edition, covering literally all our areas and also giving space to current opinion articles, for example in relation to society and the effects of COVID -19.

In addition to this change, we would like to remind you of our current Demetrios Award. Don't forget that you can now submit your research and opt for the 500 Euro prize plus publication of the work in our Journal. You can immediately submit your work by mail to admin@joshaarchive.org to participate. Keep connected with our social media accounts (Facebook \& Instagram) to see and get more information about this wonderful idea to promote and support the talent of young students all around the world.

In the same way, we are proud to show an increase in the number of visits and downloads in all our articles. This explains not only the need to find free and valuable information, but also the need to share your own research with the world through this online platform!.
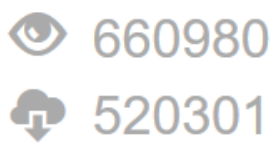

Ilı Stats

We are happy to carry on a successful way with all your support and hope to have a wonderful spring overflowing with endless interesting articles from all over the world. Together, we have achieved so much exile in such a short time. Therefore, we thank you and promise to continue to work to connect more authors around the world and continue to share important knowledge, because the knowledge that is not communicated is wasted knowledge! 
The Editorial Board and everybody in JOSHA would like to thank our readers and authors for supporting this project.

We wish all our readers a joyful reading experience at JOSHA!

\section{Table of content: $\underline{\text { http://josha-journal.org/en/issues }}$}

Franziska Buttgereit, Flatten the curve \#stayhome Feelings of Isolation: Loneliness or Being $\underline{\text { Alone }}$

Ezequiel Calvo Roitberg, Immortal

Joachim Frank, Nobel Laureate Joachim Frank: Convocation Speech at Indian Statistical $\underline{\text { Institute }}$

Linus Akudolu, A Philosophical Inquiry into the Nature and Problems of Religious Experience

Gerhard Steinmann, Stephan Seiler, María Fernanda Sandoval, Roland

Mertelsmann, Demetrios Award 2020

Tatiana Castañeda, Perfil Clinico de Pacientes con Trastornos de la Conducta Alimentaria.

Frank Wertheimer, Die Änderung von Chefarztverträgen - The Change of Chief Physician Contracts

Ezequiel Calvo Roitberg, Inmortal

Gisela Pattarone, Automatic Breast Cancer Cell Classification using deep Convolutional neural Networks

Manfred Löwisch, Paul Schempps Streit mit dem Oberkirchenrat

Sol Minoldo, Juan Cruz Balian, La lengua degenerada

Ignacio Mastroleo, Felicitas Holzer, Roland Mertelsmann, Research on genetic Databases:

Duties of Rescue and equal Respect to all

Franziska Buttgereit, Systemic Relevance - of Culture and Freelancers in Times of

unpredictable global Events: The Corona Crisis

Eduard Kaeser, Der Mensch ist der Mikrobe egal - wir täten gut daran, Krankheit vermehrt als ökologisches Problem zu begreifen 
Guadalupe Nogués, Thinking with Others. A survival Guide in times of post-Truth - Of Words and Things, Chapter 1

Franziska Buttgereit, Stage fright - blessing or curse?

Carmine Cataldo, Jazz Arranging for Beginners - Part 2 [Tecniche di Arrangiamento Jazz per Principianti - Seconda Parte]

Carmine Cataldo, Jazz Arranging for Beginners - Part 1 [Tecniche di Arrangiamento Jazz per Principianti - Prima Parte]

Femi Omotoso, Goke Kuti, Isaac Olayide O. Oladeji, Assessment of the (Inter) Dependency of Economic Relations between Nigeria and China: 1999-2019

Bujar Q. Bajçinovci, Bard Bajçinovci, Uliks Bajçinovci, Architectural Design Process: Consulting with Nature

Guadalupe Nogués, PENSAR CON OTROS, La Era de la Posverdad - Las palabras y las cosas, Capitulo 1- THINKING WITH OTHERS: A survival quide in times of post-truth

Harald A. Mieg, Learning by Research - A First Résumé. Forschendes Lernen - eine erste Bilanz

Maria Fernanda Sandoval on behalf of the JOSHA Team 